Reprinted from the Journal of Production Agriculture

Volume 4, no. A, October-December 1991

677 South Segoe Rd., Madison, WI 53711 USA

\title{
Tillage and Cropping System Effects on Cotton Yield and Profitability on the Texas Southern High Plains
}

Eduardo Segarra, J. Wayne Keeling, and John R. Abernathy 


\title{
Tillage and Cropping System Effects on Cotton Yield and Profitability on the Texas Southern High Plains
}

\author{
Eduardo Segarra,* J. Wayne Keeling, and John R. Abernathy
}

Furrow irrigated and dryland cotton (Gossypium hirsutum L.) cropping systems for the Texas Southern High Plains were ranked according to stochastic dominance with respect to a function (SDRF). It was found that under furrow irrigation some of the cropping systems are superior to conventional cotton practices. Also, under dryland, it was found that all of the cotton cropping systems analyzed were superior to conventional cotton practices. Thus, the cotton cropping systems analyzed seem to be viable alternatives to current cotton production practices in the area.

$\mathrm{C}$ OTTON is the most important agronomic crop on the Texas Southern High Plains (TSHP) in terms of both acreage and crop value. Between 2.6 and 3.3 mil-

Eduardo Segarra, Dep. of Agricultural Economics, Majl Stop 2132 , Texas Tech Univ., Lubbock, TX 79409-2132; J.W. Keeling and J.R. Abernathy, Texas Agric. Exp. Sin., Lubbock, TX 79401. Publication T-1-325 of the College of Agric. Sci., Texas Tech Univ. and Technical Article TA-25897 of the Texas Agric. Exp. Stn. Received 24 Sept. 1990. *Corresponding author.

Published in J. Prod. Agric. 4:566-571 (1991). lion acres of cotton are planted annually in the 25 -county region. Approximately $50 \%$ of this acreage is irrigated from the Ogallala aquifer. Although year-to-year yield variations are high, the overall trend since 1965 , for both irrigated and dryland yields, has been down (Neal and Ethridge, 1986). This trend has significantly reduced profitability, increasing financial stress in the area.

Since 1973, higher returns from cotton than from alternative crops has led to conventional-tillage cotton monoculture. Conventional-tillage cotton production in this area includes operations for destroying stalks, deeptillage with moldboard or chisel plow, preplant herbicide incorporation, bedding, planting, and cultivation for

\footnotetext{
Abbrevintions: ARAC, absolute risk aversion coefficient; CONVTILL, conventional tillage cotton praduction system; FDSD, first degree stochastic dominance; NOTILL, no-till cotton irrigated production system; REDTILL, reduced till cotton irrigated production sy5tem; SDRF, stochastic dominance with respect to a function; SDSD, second degree stochastic dominance; SORG-COT, sorghum-cotton irrigated production system; TSHP, Texas Southern High Plains; TWC, terminated wheat-cotton irrigated production system; WHEAT-COT, wheat-cotton irrigated production system.
} 
Table 1. Operations performed within each cotton system at the Texas Agricultural Experiment Station, Lubbock.

\begin{tabular}{|c|c|c|c|c|}
\hline \multirow[b]{3}{*}{ Conventional } & \multirow{2}{*}{\multicolumn{2}{|c|}{ Continuous cotton }} & \multicolumn{2}{|c|}{ Conservation-till rotations } \\
\hline & & & \multirow{2}{*}{$\begin{array}{c}\text { Terminated } \\
\text { wheat-cotton }\end{array}$} & \multirow{2}{*}{$\begin{array}{l}\text { Sorghum or } \\
\text { whent-cotton }\end{array}$} \\
\hline & Reduced till & No-till & & \\
\hline Shred stalks & Shred stallss & $\begin{array}{l}\text { Spray. } \\
2,4-D+\text { diuron }\end{array}$ & Plant wheat & $\begin{array}{l}\text { Spray- } \\
2,4-D+\text { diuron }\end{array}$ \\
\hline Disc & $\begin{array}{l}\text { List incorporate- } \\
\text { trifluralin and } \\
\text { fertilizer }\end{array}$ & $\begin{array}{l}\text { Plant-spray- } \\
\text { glyphosate }+ \\
\text { metolachlor }+ \\
\text { prometryn + caparol }\end{array}$ & $\begin{array}{l}\text { Spray-glyphosate } \\
\quad+\text { diuron }\end{array}$ & $\begin{array}{l}\text { Plant-apray- } \\
\text { glyphosate }+ \\
\text { dual }+ \text { caparol }\end{array}$ \\
\hline & $\begin{array}{l}\text { Plant-spray- } \\
\text { caparol }\end{array}$ & Cultivate (1) & Cultivate $\{1\}$ & Cultivate (I) \\
\hline Bed & Rotary hoe & $\begin{array}{l}\text { Irrigate† } \\
\text { Hurvest }\end{array}$ & $\begin{array}{l}\text { Irrigate† } \\
\text { Harvest }\end{array}$ & $\begin{array}{l}\text { Irrigate† } \\
\text { Harvest }\end{array}$ \\
\hline
\end{tabular}

† Not applicable to dryland plats.

weed control. Typically, 12 to 15 tillage operations are preformed prior to harvest.

Conservation tillage systems in which the crop is planted into residue from previous crops have shown potential for reducing machinery, fuel, and labor costs (CAST, 1977). Additional benefits from these systems include preservation of soil moisture (Unger and Wiese, 1979), reduction of wind and water erosion (Christensen and Norris, 1983, and McGregor et al., 1975), increased yields, and profitability, primarily due to longer machinery life (Harman et al., 1989).

Conservation tillage in cotton production has gained less acceptance than in other crops because weeds are more competitive in cotton (McWhorter and Jordan, 1985). Buildup of annual weeds and johnsongrass [Sorghum halepense (L.) Pers.] may reduce cotton yields in minimum tillage as compared with conventional tillage (Brown et al., 1987). It has been suggested, however, that the potential for conservation or no-till cotton production is greater in the Southern Plains than in other cotton growing regions because of less severe weed infestations (McWhorter and Jordan, 1985).

Conservation tillage systems have gained increased interest in the TSHP as a means to increase profitability. Conservation tillage can also contribute toward reducing erosion on highly erodible lands as required by Conservation Compliance provisions of the 1985 Food Security Act (Federal Register, 1987).

Final acceptance and widespread use of conservation tillage cotton production systems ultimately will depend on how their economic performance compares with current conventional tillage cotton production practices in this region. The objective of this study was to evaluate effects of conservation tillage cotton production systems in rotation with wheat (Triticum aestivum L.) or sorghum
[Sorghum bicolor (L.) Moench.] on cotton lint yield and profitability under irrigated and dryland conditions at Lubbock, Texas. Stochastic dominance with respect to a function was used to rank the cropping systems analyzed.

\section{MATERIALS AND METHODS}

Two experiments were established at the Texas Agricultural Experiment Station at Lubbock in 1986. Separate furrow-irrigated and dryland experiments were conducted on an Acuff loam (fine-loamy, mixed, thermic Aridic Paleustolls) which contained $50 \%$ sand, $21 \%$ silt, and $29 \%$ clay, with a pH of 7.8. Each cropping system plot was 26 - by $50-\mathrm{ft}$ with 4 yearly replications arranged in a randomized block design.

Treatments (cropping systems) included conventional tillage, reduced till, and no-till continuous cotton, and conservation tillage rotation with terminated wheat, wheat, or sorghum. Cropping sequences and tillage systems were established in 1986 and data collected for the 1987 through 1989 crop years. The plot area had been in continuous cotton production for $5 \mathrm{yr}$.

Agronomic inputs, tillage practices, and herbicides used each year are summarized in Table 1 . In conventionaltillage continuous cotton, standard land preparation, herbicide, and tillage practices were used. In the reducedtill continuous cotton, deep tillage was eliminated and trifluralin was incorporated in the bedding operation. In no-till continuous cotton, the crop was planted into the old stalks without any tillage. Winter weeds were controlled with an early preplant application of 2,4-D + diuron. Glyphosate was applied at planting as a burndown to emerged weeds and metolachlor + prometryn was applied pre-emergence. Similar herbicide treatments 
Table 2. Rainfall by month at Lubbock, 1987-1989. $\dagger$

\begin{tabular}{|c|c|c|c|c|}
\hline Month & 1987 & 1988 & 1989 & $75 \cdot y r$ avg. \\
\hline January & 0.69 & 0.30 & 0.45 & 0.49 \\
\hline February & 1.13 & 0.42 & 1.04 & 0.64 \\
\hline March & 0.47 & 0.25 & 0.68 & 0.86 \\
\hline April & 0.04 & 1.41 & 0.28 & 1.24 \\
\hline May & 5.19 & 2.29 & 0.40 & 2.70 \\
\hline June & 2.27 & 1.56 & 4.91 & 2.60 \\
\hline July & 3.74 & 3.35 & 0.31 & 2.18 \\
\hline August & 1.40 & 0.42 & 3.37 & 2.05 \\
\hline September & 2.55 & 2.48 & 3.51 & 2.52 \\
\hline October & 0.75 & 0.10 & 0 & 2.03 \\
\hline Navember & 0.12 & 0.22 & 0 & 0.62 \\
\hline December & 1.29 & 0.51 & 0.22 & 0.62 \\
\hline Totals & 19.66 & 13.32 & 14.90 & 18.73 \\
\hline
\end{tabular}

† National Weather Service, Lubbock, TX.

were used on the wheat-cotton, and sorghum-cotton rotations. In the terminated wheat-cotton system, wheat was drilled into the cotton stalks after harvest as a winter cover crop. The wheat was terminated with glyphosate at $0.38 \mathrm{lb} /$ acre in April.

Fertilizer applications were based on yearly soil tests of each plot. Fertilizer applications were 60 to $80 \mathrm{lb}$ $\mathrm{N} / \mathrm{acre}$ and $40 \mathrm{lb} \mathrm{P} / \mathrm{acre}$ for irrigated cotton and 20 to $30 \mathrm{lb} \mathrm{N} /$ acre and $20 \mathrm{lb} \mathrm{P} /$ acre for dryland cotton. Irrigated treatments were furrow-irrigated based on rainfall patterns and crop-growth stages. Cotton lint yield was determined by harvesting and ginning $13 \mathrm{ft}$ of two rows from each plot. Gross returns per acre were calculated as lint yield times the market price and did not reflect government deficiency payments. Total costs of production were separated into two components: preharvest costs and harvest costs. Because harvesting costs are a function of actual cotton yields, they varied across cropping systems. Cost of mechanical operations were based on the Texas crop enterprise budgets (TAES, 1989). Variable input costs were based on local prices for seed, fertilizer, herbicide, and irrigation. Average yields and/or returns performance of cropping systems across years, provide a good overall indicator of the relative profitability of the systems. Producers, however, are concerned not only with the "average" performance of their practices or operations, but also with their within-year and year-to-year variability. For this reason, SDRF was used to rank the cropping systems analyzed.

The SDRF is a valuative criterion that is used to order actions or choices for classes of decisionmakers defined by specified lower and upper bounds of their absolute risk aversion coefficient (ARAC), R(x), (Arrow, 1971, and Pratt, 1964). The ARAC is defined as $R(x)=$ $-U^{\prime \prime}(x) / U^{\prime}(x)$ where $U^{\prime}(x)$ and $U^{\prime \prime}(x)$ are the first and second derivatives of a von Neumann-Morgenstern utility function with respect to the performance measure, usually specified in monetary terms. In general, $U^{\prime}$ is assumed to be positive if "more" of the performance measure is preferred to "less." If $\mathrm{R}(\mathrm{x})$ is positive, implying that $U$ " is negative, the underlying utility function is concave and the decisionmaker is said to be risk averse. On the other hand, if $R(x)$ is negative, implying that $U^{\prime \prime}$ is positive, the underlying utility function is convex and the decisionmaker is said to be a risk lover. Thus, the value
Table 3. Average cotton lint yields as influenced by irrigated and dryland cropping systems at Lubbock, TX, 1987-1989.

\begin{tabular}{|c|c|c|c|c|c|}
\hline \multirow[b]{3}{*}{ Cropping system $†$} & \multicolumn{5}{|c|}{ Yields } \\
\hline & \multirow[b]{2}{*}{1987} & \multirow[b]{2}{*}{1988} & \multirow[b]{2}{*}{1989} & \multicolumn{2}{|c|}{$1987-1989$} \\
\hline & & & & Average & $\begin{array}{l}\text { Standard } \\
\text { deviation }\end{array}$ \\
\hline \multicolumn{6}{|l|}{ Irrigated } \\
\hline $\begin{array}{l}\text { Conventional till } \\
\text { Reduced till } \\
\text { No-till } \\
\text { Terminated }\end{array}$ & $\begin{array}{l}801.25 \\
769.00 \\
806.00\end{array}$ & $\begin{array}{r}964.25 \\
1020.75 \\
1050.50\end{array}$ & $\begin{array}{l}\mathbf{6 1 3 . 2 5} \\
\mathbf{5 8 5 . 5 0} \\
\mathbf{5 7 8 . 5 0}\end{array}$ & $\begin{array}{l}792.91 \\
791.75 \\
811.66\end{array}$ & $\begin{array}{l}177.84 \\
190.87 \\
200.54\end{array}$ \\
\hline $\begin{array}{l}\text { wheat-cotton } \\
\text { Wheat-cotton } \\
\text { Sorghum-cotton }\end{array}$ & $\begin{array}{l}965.25 \\
952.00 \\
903.25\end{array}$ & $\begin{array}{r}956.75 \\
1027.25 \\
855.50\end{array}$ & $\begin{array}{l}549.00 \\
499.00 \\
515.50\end{array}$ & $\begin{array}{l}823.66 \\
826.08 \\
758.08\end{array}$ & $\begin{array}{l}219.31 \\
244.30 \\
188.72\end{array}$ \\
\hline \multicolumn{6}{|l|}{ Dryland } \\
\hline $\begin{array}{l}\text { Conventional till } \\
\text { Reduced till } \\
\text { No-till } \\
\text { Termingted }\end{array}$ & $\begin{array}{l}690.75 \\
846.25 \\
833.25\end{array}$ & $\begin{array}{l}230.75 \\
342.75 \\
280.00\end{array}$ & $\begin{array}{l}160.25 \\
212.75 \\
209.00\end{array}$ & $\begin{array}{l}360.58 \\
467.25 \\
440.75\end{array}$ & $\begin{array}{l}242.27 \\
279.39 \\
284.53\end{array}$ \\
\hline $\begin{array}{l}\text { wheat-cotton } \\
\text { Wheat-cotton } \\
\text { Sorghum-cotton }\end{array}$ & $\begin{array}{l}816.75 \\
738.00 \\
753.75\end{array}$ & $\begin{array}{l}252.00 \\
441.75 \\
284.25\end{array}$ & $\begin{array}{l}169.75 \\
551.50 \\
223.75\end{array}$ & $\begin{array}{l}412.83 \\
577.08 \\
423.91\end{array}$ & $\begin{array}{l}290.03 \\
147.03 \\
237.30\end{array}$ \\
\hline
\end{tabular}

$\dagger$ Denotes 1988-1989 crop sequences.

of the ARAC provides a local valuation of the degree of concavity or convexity of the utility function of the decisionmaker.

As pointed out by King and Robison (1981), the most important property of the ARAC is that it provides a unique measure of preferences, while the utility function is unique only to a positive linear transformation. What SDRF does is order choices on the basis of the specified lower and upper bounds of the decisionmaker's ARAC. The SDRF criterion is more flexible than other stochastic dominance approaches, such as first- and seconddegree stochastic dominance (FDSD and SDSD), because SDRF allows precise valuation of the choices for the selected lower and upper bounds of the ARAC.

The underlying lower and upper bounds of the ARAC under FDSD are minus infinity and plus infinity, and the lower and upper bounds of the ARAC under SDSD are zero and plus infinity. By contrast, the lower and upper bounds of the ARAC under SDRF are specified by the researcher to whatever values are deemed to. be appropriate.

\section{RESULTS AND DISCUSSION}

Timely rains enhanced dryland production in 1987 while poor rainfall in 1988 and 1989 limited growth and cotton yield potential (Table 2). For purposes of showing the relative dispersion of the cropping systems analyzed, their corresponding yearly average and overall period average, and standard deviation of cotton lint yields are depicted in Table 3. Information with respect to the statistical significance of the means is provided by Keeling, 1987, 1988, and 1989. Under furrow-irrigated conditions, high yields were obtained with all cropping systems in 1987 and 1988. Irrigated yields, however, were lower in 1989 than in 1987 and 1988 for all cropping systems, due to an early freeze. Lower-than-average rainfall during the 1988 and 1989 growing seasons significantly affected dryland yields. Cotton lint yields 
Table 4. Average production costs, gross and net revenues in 1989 prices for irrigated cotton systems at Lubbock, TX, $1987-1989$.

\begin{tabular}{|c|c|c|c|c|c|c|c|c|c|}
\hline \multirow[b]{3}{*}{ Cropping system } & \multicolumn{3}{|c|}{ Preharvest costs } & \multirow{3}{*}{$\begin{array}{c}\text { Total } \\
\text { preharvest } \\
\text { costs }\end{array}$} & \multirow{3}{*}{$\begin{array}{l}\text { Harvest } \\
\text { costs }\end{array}$} & \multirow{3}{*}{$\begin{array}{l}\text { Total } \\
\text { production } \\
\text { costs }\end{array}$} & \multirow{3}{*}{$\begin{array}{c}\text { Gross } \\
\text { revenuesł }\end{array}$} & \multicolumn{2}{|c|}{ Net revenue above } \\
\hline & \multicolumn{2}{|c|}{ Variable } & \multirow{2}{*}{$\frac{\text { Fixed }}{\text { Machinery }}$} & & & & & Proharyost & \\
\hline & $\mathrm{H}, F, \mathrm{~S}, \mathrm{I} \dagger$ & Machinery & & & & & & costs & costs \\
\hline \multicolumn{10}{|l|}{ Continuous cotton } \\
\hline $\begin{array}{l}\text { Conventional tillage } \\
\text { Reduced tillage } \\
\text { No-till } \\
\text { Terminated wheat-cotton }\end{array}$ & $\begin{array}{r}83.10 \\
83.10 \\
110.11 \\
115.82\end{array}$ & $\begin{array}{r}21.89 \\
12.81 \\
5.21 \\
6.32\end{array}$ & $\begin{array}{r}26.94 \\
21.67 \\
7.66 \\
9.50\end{array}$ & $\begin{array}{l}131.93 \\
117.58 \\
122.98 \\
131.65\end{array}$ & $\begin{array}{l}49.57 \\
49.50 \\
50.78 \\
51.66\end{array}$ & $\begin{array}{l}181.50 \\
167.08 \\
173.76 \\
183.30\end{array}$ & $\begin{array}{l}469.71 \\
453.96 \\
461.33 \\
472.59\end{array}$ & $\begin{array}{l}391.78 \\
336.38 \\
338.35 \\
340.94\end{array}$ & $\begin{array}{l}282.21 \\
286.88 \\
287.57 \\
289.28\end{array}$ \\
\hline $\begin{array}{l}\text { Wheat-cotton } \\
\text { Sorghum-cotton }\end{array}$ & $\begin{array}{l}106.99 \\
111.15\end{array}$ & $\begin{array}{l}4.34 \\
5.29\end{array}$ & $\begin{array}{l}6.46 \\
7.76\end{array}$ & $\begin{array}{l}117.80 \\
124.13\end{array}$ & $\begin{array}{l}51.58 \\
47.55\end{array}$ & $\begin{array}{l}169.64 \\
171.68\end{array}$ & $\begin{array}{l}472.25 \\
438.85\end{array}$ & $\begin{array}{l}354.45 \\
314.72\end{array}$ & $\begin{array}{l}302.61 \\
267.17\end{array}$ \\
\hline
\end{tabular}

$\dagger$ Herbicide, fertilizer, seed, and irrigation input costs.

$\ddagger$ Does not include deficiency payments.

Table 5. Average production costs, gross and net revenues in 1989 prices for dryland cotton systems at Lubbock, TX, 1987-1989.

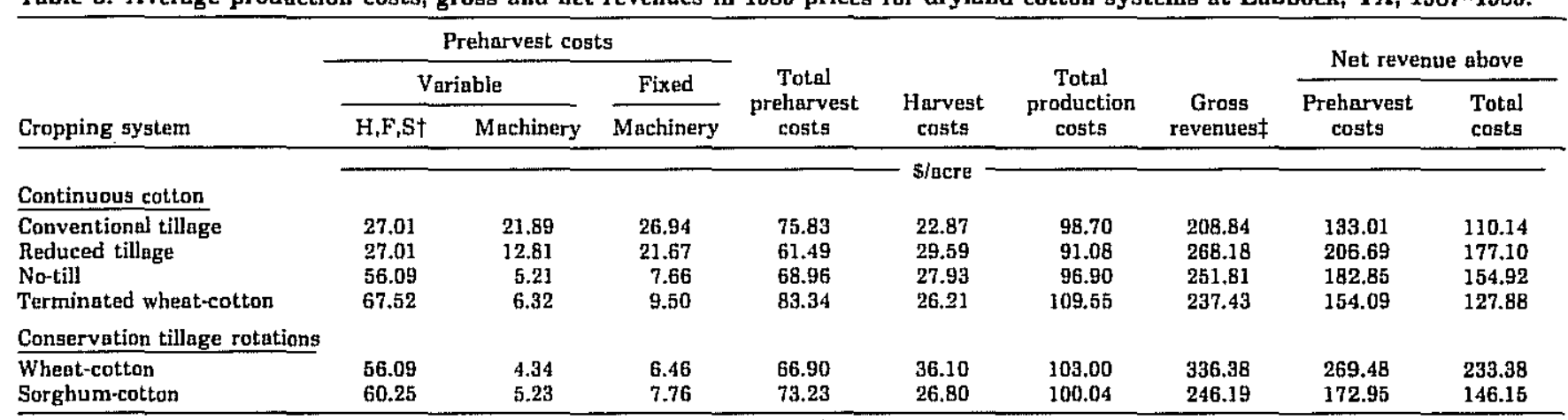

$\dagger$ Herbicide, fertilizer, and seed input costs.

$\ddagger$ Does not include deficiency payments.

in 1988 were lower than those in 1987 for all the cropping systems, and yields in 1989 were lower than those in 1988 for all but one cropping system. Average production costs, gross and net revenues for the irrigated and dryland cropping systems for the 1987-1989 period are depicted in Tables 4 and 5, respectively. It is important to point out that the gross revenue figures in Tables 4 and 5 do not reflect deficiency payments, and that there were slight differences among prices of cotton lint under the alternative cropping systems, mainly due to fiber quality variations. The average monetary figures in Tables 4 and 5 are depicted in 1989 prices. The 1987 and 1988 monetary figures were inflated to 1989 prices by using the Gross Domestic Product deflator.

Information in Table 4 indicates that the best system, in terms of net revenues above total costs of production, under irrigation was the wheat-cotton cropping system. The net revenue above total costs of production figures of the other systems, however, except those of the sorghum-cotton system, were very close to the net revenue figures of the wheat-cotton system. The descending order ranking of the systems, according to net revenues above total costs of production, under irrigation was: wheatcotton (WHEATCOT), terminated wheat-cotton (TWC), no-till cotton (NOTILL), reduced tillage cotton (REDTILL), conventional tillage cotton (CONVTILL), and sorghum-cotton (SORGCOT). This same ranking of the systems holds under the net revenue above preharvest costs figures in Table 4.

As shown in Table 5, the wheat-cotton cropping system was found to outperform the other cropping systems under dryland conditions by a larger margin. That is, under dryland conditions the differences between both, net revenues above total cost of production and net revenues above preharvest costs, across cropping systems were larger than the differences under irrigation. The descending order ranking of the systems, according to the net revenue above total costs of production, under dryland was: WHEATCOT, REDTILL, NOTILL, SORGCOT, TWC, and CONVTILL. Again, this same ranking of the systems holds under the net revenue above preharvest costs figures in Table 5.

Given the importance to agricultural producers of minimizing year-to-year variability of their income, the cropping systems were ranked using SDRF in order to: (i) determine if the ranking of the cropping systems might be different for alternative levels of ARAC, and (ii) confirm if the ranking by using "averages" (as depicted in Tables 4 and 5) prevailed. Using the 12 cotton lint yield data points available ( $3 \mathrm{yr}$ with four replications per year) for each of the cropping systems and using 1989 input cost of production and cotton prices data, 12 net revenue figures were derived for each of the cropping systems analyzed. Using King and Robison's (1981) SDRF methodology, these net revenue figures were compared using alternative lower- and upper-bound ARAC intervals.

Overall, twenty alternative ARAC intervals contained in the 0.0500 to -0.0500 range, similar to those used by Kramer and Pope, 1981, King and Robison, 1981, Williams et al., 1989, and others were used. After considering the alternative ARAC interval scenarios, however, it was found that the results were robust. That is, the rank- 
ing of the cropping systems did not change at all as the ARAC intervals were modified. This indicates that the ranking of the systems remains the same, regardless of the level of risk aversion of the decision maker. The results of comparing the distributions of net revenues across cropping systems are presented in Table 6. A "1" to the right of the particular pair of systems under either irrigated or dryland, indicates that the first cropping system dominates the second. A " -1 " to the right of a particular pair of systems under either irrigated or dryland, indicates that the first cropping system is dominated by the second. Although we did not have any, a " 0 " would have indicated that neither cropping system dominates. For example, under the irrigated column for the CONVTILL-TWC comparison, there is a " -1 " to the right. This indicates, that the CONVTILL cropping system distribution of net revenues is dominated by the distribution of net revenues associated with the TWC cropping system. Conversely, going down in the same column, under the TWC-CONVTILL comparison, we can see that there is a " 1 " to the right, indicating a similar result.

Careful examination of the information contained in Table 6 indicates that under irrigation the REDTILL system is dominated by all the other systems, and that the WHEATCOT system dominates all the other systems. The underlying descending ranking for the cropping systems under irrigation is: WHEATCOT, TWC, CONVTILL, NOTILL, SORGCOT, and REDTILL. Also, as can be seen in Table 6, under dryland conditions the CONVTILL system is dominated by all other systems, and again the WHEATCOT system dominates all other systems. The underlying descending ranking of the systems under dryland is: WHEATCOT, REDTILL, NOTILL, TWC, SORGCOT, and CONVTILL.

Comparing the underlying rankings of the systems under irrigation using SDRF (Table 6) to those obtained by evaluating the "average" performance of the systems (Table 4), it can be seen that the two top-ranked systems were ranked the same under both evaluation criteria. It is important to note, however, that the ranking of the remaining four systems is different under both evaluation criteria. With respect to the dryland systems, it was found that the top three ranked systems and the lastranked system were ranked the same under both evaluation criteria. Thus, the results seem to be more robust across evaluation criteria, for the dryland systems than for the irrigation systems.

It is important to point out that the rankings of the systems under SDRF is superior to that obtained by comparing "average" performance of the systems. This is because the former not only takes into consideration "average" performance, but their variability as well. Therefore, it is important to keep in mind that, if variability is not considered in comparing or evaluating practices and/or alternative courses of action available to decisionmakers, misleading results could be obtained.

As pointed out above, the most widely used practice in the TSHP is the CONVTILL system. Two of the cropping systems under irrigation and all of the cropping systems under dryland analyzed here, have been shown to
Table 6. Stochastic dominance with respect to a function results for irrigated and dryland cropping systems.

\begin{tabular}{|c|c|c|c|}
\hline \multicolumn{4}{|c|}{ Cropping systems $\dagger$} \\
\hline Irrigated & & Dryland & \\
\hline $\begin{array}{l}\text { CONVTILL-NOTILL } \\
\text { CONVTILL-TWC } \\
\text { CONVTILL-REDTILL } \\
\text { CONVTILL-SORGCOT } \\
\text { CONVTILL-WHEATCOT }\end{array}$ & $\begin{array}{r}1 \\
-1 \\
1 \\
1 \\
-1\end{array}$ & $\begin{array}{l}\text { CONVTILL-NOTILL } \\
\text { CONVTILL-TWC } \\
\text { CONVTILL-REDTILL } \\
\text { CONVTILL-SORGCOT } \\
\text { CONVTILL-WHEATCOT }\end{array}$ & $\begin{array}{l}-1 \\
-1 \\
-1 \\
-1 \\
-1\end{array}$ \\
\hline $\begin{array}{l}\text { NOTILL-CONVTILL } \\
\text { NOTILL-TWC } \\
\text { NOTILL-REDTILL } \\
\text { NOTILL-SORGCOT } \\
\text { NOTILL-WHEATCOT }\end{array}$ & $\begin{array}{r}-1 \\
-1 \\
1 \\
1 \\
-1\end{array}$ & $\begin{array}{l}\text { NOTILL-CONVTILL } \\
\text { NOTILL-TWC } \\
\text { NOTILL-REDTILL } \\
\text { NOTILL-SORGCOT } \\
\text { NOTILLWHEATCOT }\end{array}$ & $\begin{array}{r}1 \\
1 \\
-1 \\
1 \\
-1\end{array}$ \\
\hline $\begin{array}{l}\text { TWC-CONVTILL } \\
\text { TWC-NOTILL } \\
\text { TWC-REDTILL } \\
\text { TWC-SORGCOT' } \\
\text { TWC-WHEATCOT }\end{array}$ & $\begin{array}{r}1 \\
1 \\
1 \\
1 \\
-1\end{array}$ & $\begin{array}{l}\text { TWC-CONVTILL } \\
\text { TWC-NOTILL } \\
\text { TWC-REDTILL } \\
\text { TWC-SORGCOT } \\
\text { TWC-WHEATCOT }\end{array}$ & $\begin{array}{r}1 \\
-1 \\
-1 \\
1 \\
-1\end{array}$ \\
\hline $\begin{array}{l}\text { REDTILL-CONVTILL } \\
\text { REDTILL-NOTILL } \\
\text { REDTILL-TWC } \\
\text { REDTILL-SORGCOT } \\
\text { REDTILL-WHEATCOT }\end{array}$ & $\begin{array}{l}-1 \\
-1 \\
-1 \\
-1 \\
-1\end{array}$ & $\begin{array}{l}\text { REDTILL-CONVTILL } \\
\text { REDTILL-NOTILI } \\
\text { REDTILL-TWC } \\
\text { REDTILL-SORGCOT } \\
\text { REDTILL-WHEATCOT }\end{array}$ & $\begin{array}{r}1 \\
1 \\
1 \\
1 \\
-1\end{array}$ \\
\hline $\begin{array}{l}\text { SORGCOT-CONVTILL } \\
\text { SORGCOT-NOTILL } \\
\text { SORGCOT-TWC } \\
\text { SORGCOT-REDTILL } \\
\text { SORGCOT-WHEATCOT }\end{array}$ & $\begin{array}{r}-1 \\
-1 \\
-1 \\
1 \\
-1\end{array}$ & $\begin{array}{l}\text { SORGCOT-CONVTILL } \\
\text { SORGCOT-NOTILL } \\
\text { SORGCOT-TWC } \\
\text { SORGCOT-REDTILL } \\
\text { SORGCOT-WHEATCOT }\end{array}$ & $\begin{array}{l}1 \\
-1 \\
-1 \\
-1 \\
-1\end{array}$ \\
\hline $\begin{array}{l}\text { WHEATCOT-CONVTILL } \\
\text { WHEATCOT-NOTILL } \\
\text { WHEATCOT-TWC } \\
\text { WHEATCOT-REDTILL } \\
\text { WHEATCOT-SORGCOT }\end{array}$ & $\begin{array}{l}1 \\
1 \\
1 \\
1 \\
1\end{array}$ & $\begin{array}{l}\text { WHEATCOT-CONVTILL } \\
\text { WHEATCOT-NOTILL } \\
\text { WHEATCOT-TWC } \\
\text { WHEATCOT-REDTILL } \\
\text { WHEATCOT-SORGCOT }\end{array}$ & $\begin{array}{l}1 \\
1 \\
1 \\
1 \\
1\end{array}$ \\
\hline
\end{tabular}

† Conventional tillage cotton (CONVTILL), No-till cotton (NOTILL), Terminated wheat-cotton (TWC), Reduced tillnge cotton (REDTILL). Sorghum-cotton (SORGCOT), and Wheat-cotton (WHEATCOT).

be more profitable and stable than the CONVTILL system for all degrees of risk aversion. Thus, the alternative cotton cropping systems analyzed seem to be viable alternatives to current practices in the TSHP. However, adoption and widespread use of the alternative cotton cropping systems analyzed here will depend upon their performance beyond the experimental level. Current efforts by researchers and cotton producers in the TSHP include incorporation of the more profitable cropping systems into a full-scale farm operation denoted as the Agricultural Complex for Advanced Research and Extension Systems. This full-scale farm operation fulfills the logical sequence of development, transfer, and adoption of efficient and environmentally sound agricultural practices linked to the sustainability concept in agriculture.

It is recognized that this study has several limitations. This analysis did not consider cotton price variability and other factors, such as size of operation and financial contraints, which might affect the variability of net returns and the risk attitudes of agricultural producers. The incorporation of these and other issues, however, would become critical when deriving optimal decision rules in a farm level setting in which other crops besides cotton form part of the decision set. In spite of these limitations and in view of the possible positive environmental impacts of the production practices analyzed here, this study provides valuable insights into the production alternatives available to producers in the TSHP. 


\section{INTERPRETIVE SUMMARY}

Conservation tillage cotton production systems in rotation with wheat or sorghum are shown to be a viable alternative to conventional cotton production practices in the Texas Southern High Plains of Texas. In particular, SDRF, which internalizes the year-to-year variability of production systems, is used to compare and rank the conservation tillage production systems relative to current conventional cotton production practices in the area. Overall, it was found that a conservation tillage cotton production system in rotation with wheat would be the most profitable production practice under dryland and furrow-irrigated conditions.

\section{REFERENCES}

Arrow, K.J. 1971. Essays in the theory of risk bearing. Marham Publishing, Chicago.

Brown, S.M., J.M. Chandler, and J.E. Morrison. 1987. Weed control in a conservation tillage rotation in the Texas Blacklands. Weed Sci. 35:695-699.

Christensen, L.A., and P.E. Norris. 1983. A comparison of tillage systems for reducing soil erosion and water pollution. USDA-ERS Agric. Econ. Rep. no. 499.

Council for Agricultural Science and Technology. 1977. Energy use in agriculture: Now and in the future. Rep. no. 68. CAST, Ames, IA. Federal Register. 1987. Highly erodible land and wetland conservation; final ruling and notice of finding no significant impact.
$52(180) \div 35193-35208$.

Harman, W.L., G.J. Michels, and A.F. Wise. 1989. A conservation tillage system for profitable cotton production in the central Texas High Plains. Agron. J. 81:615-618.

Keeling, J.W. 1987, 1988, and 1989. Cropping systems research at the Texas Agric. Exp. Stn. Lubbock. Texas Agric. Exp. Stn. Annu. Prog. Rep.

King, R.P., and L.J. Robison. 1981. Implementation of the interval approach to the measurement of decision maker preference. Michigan St. Univ. Agric. Exp. Stn. Res. Rep. 418.

Kramer, R.A., and R.D. Pope. 1981. Participation in farm commodity programs: A stochastic dominance analysis. Am. J. Agric. Econ. 63:119-128.

McGregor, K.C., J.D. Green, and G.E. Gurley. 1975. Erosion control with no-till cropping practices. Trans. ASAE 18:189-200.

McWhorter, C.G., and T.N. Jordan. 1985. Limited tillage in cotton production. p. 61-76. In Weed control in limited-tillage systems. Weed Sci. Soc. Am., Champaign, IL.

Neal, T.J., and D.E. Ethridge. 1986. Analysis of Texas High Plains cotton yields trends. Texas Tech Univ. College of Agric. Sci. Publ. $\mathrm{T}-1-242$.

Pratt, J.W. 1964. Risk aversion in the small and in the large. Econometrica 32:122-136.

Texas Agricultural Extension Service. 1989. Texas crop enterprise budgets. Texas A\&M Univ., College Station.

Unger, P.W., and A.F. Wise. 1979. Managing irrigated wheat residues for water storage and subsequent dryland sorghum production. Soil Sci. Soc. Am. J. 43:582-588.

Williams, J.R., M.F. Crisostomo, R.O. Burton, Jr., K.W. Kelley, and R.V. Liewelyn. 1989. A risk analysis of crop rotations in southeast Kansas including double-crop alternatives. Kansas Agric. Exp. Stn. Staff Paper no. 89-299-D. 